\title{
THE IMPORTANCE OF NEGOTIATION IN JURISPRUDENCE IN LATVIA
}

\author{
Kristaps Gailis ${ }^{1}$, Juna Kjaksta ${ }^{2}$ \\ ${ }^{1} \mathrm{Mg}$. iur, lecturer, Rezekne Academy of Technologies, Rezekne, Latvia, \\ e-mail: kristaps.gailis@rta.lv \\ ${ }^{2}$ Mg. iur, lecturer, Rezekne Academy of Technologies, Rezekne, Latvia, \\ e-mail: Juna.Kjaksta@rta.lv
}

\begin{abstract}
The world around us is changing, but some spheres lag behind the changes. Jurisprudence has a long history with established traditions and values. It may be time to look at the values and compare them with the demands and lively dynamics of modern society. Therefore, this research is focused on finding out the role and importance of negotiation in jurisprudence in Latvia. As jurisprudence belongs to the social sciences, it is important to look at socio-historical aspects and analyse different author books and publications in the field. Thus, it could be concluded that the importance of negotiation has so far been underestimated. While the state is trying to make the legal system more effective, it does not pay sufficient attention to aspects that will make a real contribution. Therefore, it can be argued in this regard that for the success story sufficient attention to the importance of negotiation in jurisprudence is missing. So far, the art of negotiating relies solely on the personal qualities, charisma, and other subjective attributes of the negotiator him/herself.
\end{abstract}

Keywords: dispute resolution, negotiations, negotiator, legal practice. JEL code: K1; F51.

\section{Introduction}

Communication is the main form of human existence. People are aggressive, conflicting creatures. Archaeological and historical records from the earliest times show them engaged in the struggle with their fellows (Himes, 1980). An integral part of the communication process is negotiation. The role of laws in society, on the other hand, is the introduction of a certain order with the aim of organizing human existence in an orderly manner. Lawyers face a constant challenge in their daily work to participate in conflict resolution. Consequently, the success of negotiations has a crucial role to play in conflict solving. That is why negotiation is very important, especially for lawyers.

Research aim: to identify the importance of conducting negotiations in jurisprudence and to understand the role of negotiation in jurisprudence.

Research tasks: to determine when negotiations have become an object of study of human social activity, an independent phenomenon to be explored, and to explore how the art of negotiation can improve the quality of jurisprudence. 
Research novelty: There are several research studies and publications in the field of negotiation. Although various subjects are taught in jurisprudence, but practical issues about the importance of negotiation and conflict resolution skills are not always addressed. Therefore, it is important to explore the importance of negotiation so that in the future it might become a separate law course in Latvia.

Research methods: descriptive method, historical method, analytical method.

Research period: $2018-2019$.

Research hypothesis: knowing how to negotiate effectively is important in jurisprudence, so it is useful to study it in depth by studying law.

\section{Negotiations are turning into science}

All human history is based on various disputes and conflict reflection. In ancient times, skirmishes between tribes and villages have evolved into larger-scale conflicts between populated areas. Humanity does not recognize diplomacy in the sense it is in nowadays. The development of science was generally limited.

The area of conflicts was also limited. Alexander's conquest of "the world" was essentially a local fight in the Middle East. The fierce incursion of Genghis Khan and his Tartar hordes across the steppes of Russia into the plains of China and India had few repercussions beyond northeast Asia. The historic struggles among the Greek city-states and the campaigns of Julius Caesar were only conflicts that left a lasting impression on the course of Western civilization (Himes 1980).

Industrialization and the formation of nation-states open up new development for humanity. From the inception of sociology, scholars in the field have been interested in the study of social conflict. Nowadays there are a lot of books, publications and materials on the Internet on the conflictsolving field, also about understanding the nature of conflict, peoples in conflict etc. These sources provide ways to resolve conflicts. Hence, negotiation is seen as one way of resolving conflicts.

Various historical, social and political events led the world to experience a First World War that was larger than ever before. On 10 January 1920 following the Paris Peace Conference that ended the First World War, the League of Nations was established. It was the first worldwide intergovernmental organization whose principal mission was to maintain world peace (Tomuschat, 1995). The organization's primary goals, as stated in its Covenant, included preventing wars through collective security and disarmament and settling international disputes through negotiation and arbitration (The Covenant of the League of Nations, 1919). 
The importance of negotiations was replaced by a role of global importance, but still it was not enough to prevent World War II.

Following World War II, the determination to prevent further war and maintain a structure of peace took a new turn. The victorious countries organized the United Nations and set out, wiser then in 1917, to establish and guarantee a structure of peace. In the late 1940s and early 1950s, there was also a flurry of research and experimentation to develop what can be called the science and technology of peace (Himes 1980). It indicates the role of negotiation not only at local level, but also at international level. Because of the importance of negotiation, it became a separate discipline in science.

\section{Trends in jurisprudence under globalization}

People have been practicing law for a very long time. Since the introduction of jurisprudence and first practicing lawyers, a long time has passed and much has changed. Geopolitical processes around the world and the Internet have brought new changes to our lives and weekdays. We can call it all in one word - globalization. Jurisprudence has also been affected by globalization. The previous distinction between Romano-Germanic and Anglo-Saxon law no longer seems so categorical. The growing influence of international treaties takes precedence over national law. References to 'globalization' not only remind us that people are increasingly connected throughout the world, but they are also a reminder that trade liberalization, new technology, and localized activity aimed at global markets, all mean that the role of the State, and the fora where States 'do business', are changing (Clapham, 1999).

Latvia belongs to the system of Romano-Germanic law. However, in recent years the judicial system has been affected by judicial precedents that are characteristic of Anglo-Saxon law. There is thus an alienation from written rights. That is why it is important for a modern lawyer to have the skills to act in an extraordinary, creative way.

Not least, the judicial system itself is constantly being improved as well. Reconciliation between the parties is one of its objectives in civil proceedings (Civil Procedure Law, 1998). A settlement between the accused and the victim may be the basis for terminating the criminal case (Criminal Procedure 2005). That is why negotiation plays an important role in the legal system. Putnam defines negotiation as a particular type of conflict management - one characterized by an exchange of proposals and counter proposals as a means of reaching a satisfactory settlement (Putnam, 1985). Nothing could be simpler or broader in scope than negotiation. Every desire that demands satisfaction - and every need to be met - is at least potentially an occasion to initiate the negotiation process (Nierenberg, 1986). 
Law in the sense of a body of laws, morals, ethical custom, customary courses of decisions, customary modes of conducting transactions, and even religious rites are found making up an undifferentiated body of precepts of social control (Pound, 1933). People's rational and irrational selves compete with each other constantly. While the work of a lawyer as grand mayor is based on balancing sociums' desires within existing law. Thus, negotiation plays an important role in the legal profession especially in the context of globalization.

Negotiation is one of the few functions in modern jurisprudence that has successfully resisted the process of standardization and the rationalization of work. Lawyers have redesigned their consulting style, customer service, but left the negotiation to individual. Negotiation is a fundamental element in the social life of organizations. Whether you are aware of it or not, you negotiate for resources and attention. Research in social psychology and behavioural economics has uncovered key principles that can help you become a better negotiator. Although the science of negotiation has developed rapidly in the last two decades, aspects of negotiation are an art (Narayanan at al., 2018). A great deal of art is also involved in the work of a lawyer. From an ancient time, the characteristics of a good lawyer were his ability to speak well, his ability as a good orator. Nowadays, the skills of an orator are important as well. Although the art of the orator must be distinguished from the art of negotiation. The common is the element of the verbal (both in orator art and in negotiation) and how verbal aspects can affect our behaviour, thinking and capturing information.

\section{The role of negotiation in jurisprudence}

Formal negotiation is a process in which interdependent people who have different goals exchange information in an attempt to produce a joint decision (Bettinghaus et al., 1987). Basically, everyone understands that, especially law students do. But the question is how much in a self-learning way we do know about negotiation as a kind of art as it was mentioned before? Law students study subjects in different areas of law. No doubt, such knowledge is very much needed, and the work of a lawyer without them is unthinkable. But for jurisprudence as an integral part of social science, not enough attention is paid to negotiation in the sense of increasing professionalism.

In the end of the days, the thing what a lawyer should do is protect his/her clients' interests. Interpretation of laws and their application basically is a playground for the lawyer, but intellectual potential in the sense of negotiation skills is a toy in lawyer hands. 
In the 1980s, experts and managers began to prefer alternative dispute resolution, that is, out of court and retreating to litigation because they were more efficient and less costly. But expectations for alternative dispute resolution quickly faded (Carver et al., 1994). But there have also been successful stories. The difference between success and failure lies in the level of trust in out-of-court dispute resolution. Whereas for the trust factor, an important role is negotiation skills.

We must keep in mind that honesty plays an important role in the lawyer's daily work. Therefore, a lawyer has a duty to act in such a manner as to save his/her client's money. In practice, lawyers often choose to bring the case to court sometimes because that way will result in a higher fee than they will resolve their dispute through negotiation. However, in Latvia such behaviour cannot always be attributed to a lack of good faith. The economic factor behind this is often not the main factor. Sometimes formal dispute resolution involves dogmatic practices that have become established over the years. However, the judicial system is looking for solutions to make dispute resolution more effective.

In the Latvian judicial system, in addition to arbitration, since 2014 there is a clause on the use of mediation. Mediation is a modern method of dispute resolution. And in Latvia it is gradually becoming more widely used. The mediation process allows the parties to the dispute to understand their true needs and interests, which can lead to a result in which both parties have satisfied their interests and needs (Kucina, 2018). Mediation can also be considered as the resolution of a dispute during negotiations. The specificity is that in the mediation process, the negotiation is led by a mediator. The mediator is a certified person to lead the mediation process. In accordance with Latvian Mediation Law requirements to be set fourth for a Certified Mediator, it is a natural person who:

1) has reached 25 years of age;

2) has impeccable reputation;

3) has acquired an education document attesting a State recognised higher education;

4) is fluent in the official language at the highest level;

5) has attended a mediator's training course;

6) has obtained a mediator's certificate (Mediation Law, 2014).

As can be seen, the negotiating skills of the specialist are dependent on his or her own personal qualities, although negotiation would be the primary objective. 


\section{Conclusions and suggestions}

In Latvia, the legal sector, just like other sectors, is undergoing changes related to globalization processes worldwide. Under these circumstances, the importance of negotiation not only in business and diplomacy but also in jurisprudence cannot be excluded. So far, negotiation as a separate area has been focused on business only, not to mention diplomacy and international relations. In legal practice, lawyers use negotiation more or less every day, but as a separate area to develop, there is little focus.

It seems that trends in jurisprudence are not aimed at improving the quality of content, but at the banal commercialization of service. Although the legal system is struggling with the problems of court busyness. In this battle of busyness, everything is based in out-of-court dispute resolution. In other words, the effectiveness of the judicial system to a large degree depends on the conduct of negotiations. At the same time, there are no changes in the legal sector aimed at improving negotiation skills.

Improving negotiation skills in jurisprudence would bring several benefits:

- in legal controversy, relationships are maintained between the disputants;

- improved intercommunication;

- both sides are the winners;

- money and time is saved;

- the decisions taken shall be based on the interests of both parties;

- the process is informal and equally inclusive;

If the process is in progress in a relaxed, informal atmosphere, with care to make both sides feel safely, then the result to be achieved will certainly be more effective. In this way, legal practice would take a new course of development that would more closely meet the demands of modern society.

\section{References}

1. Bettinghaus, E.P., Cody, M.J. (1987). Persuasive Communication (4th ed). New York: Holt, Rinehart \& Winston.

2. Carver, T.B., Vondra, A. (1994). Alternative dispute resolution. When it works when not. Harvard business Review on Negotiation and Conflict Resolution. Rīga: Lietišksās izdevniecības dienests.

3. Clapham, A. (1999). Globalization and the Rule of Law. Review of the International Commission of Jurists. Retrieved from https://www.businesshumanrights.org/sites/default/files/reports-and-materials/Globalization-and-theRule-of-Law.htm

4. Himes, J.S. (1980). Conflict and Conflict Management. The University of Georgia Press: Athens. 
5. International treaty (1919). The Covenant of the League of Nations. League of Nations. Retrieved from https://avalon.law.yale.edu/20th_century/leagcov.asp

6. Kucina, I. (2018). Mediācijas atīstība Latvijā; Pilotprojektu rezultāti. Tieslietu Ministrija. Retrieved from https://www.tm.gov.lv > files > veidlapas > Mediācija.

7. Latvian Law (1998). Civil Procedure law. Section 149. Latvijas Vēstnesis, 326/330, Retrieved from https://likumi.lv/ta/en/en/id/50500-civil-procedure-law

8. Latvia Law (2005). Criminal Procedure Law. Chapter 48. Latvijas Vēstnesis, 74, 11.05.2005. Retrieved from https://likumi.lv/ta/en/en/id/107820-criminalprocedure-law

9. Latvia Law (2014). Mediation Law. Latvijas Vēstnesis 108, 04.06.2014. Retrieved September 27, 2019, from https://likumi.lv/ta/en/en/id/266615-mediation-law

10. Narayanan, J., Buche, I., McTeague, L. (2018). IMD. Research and Knowledge. The art and science of negotiation. Retrieved September 27, 2019, from https://www.imd.org/research-knowledge/articles/negotiation-skills-to-achievepositive-outcomes/

11. Nierenberg, G.I. (1986). The complete Negotiator. New York: Nierenberg \& Zeif Publisher.

12. Pound, R. (1933). Law and the Science of Law in Recent Theories. A Symposium held at the Thirty-First Annual Meeting of the Association of American Law Schools in Chicago.

Retrieved from https://heinonline.org/HOL/LandingPage?handle=hein.journals/amerlsr7\&div=1 07\&id=\&page

13. Putnam, L.L. (1985). Bargaining as Organizational Communication. Organizational Communication: Traditional Themes and New Directions. Newbury Park: Sage.

14. Tomuschat, C. (1995). The United Nations at Age Fifty. A Legal Perspective. The Hague/London/Boston: Kluwer Law International. 